\title{
Practices of Midwives in the Use of Personal Protective Equipment when Aid Labor during the COVID-19 Pandemic
}

\section{Shinta Novelia ${ }^{1 *}$, Rosmawati Lubis ${ }^{2}$, Reny Murniati ${ }^{3}$, Bunga Tiara Carolin ${ }^{4}$}

1,2,3,4Midwifery Department, Universitas Nasional Jakarta, Indonesia; shinta.novelia@civitas.unas.ac.id (Corresponding Author)

\section{Article Info: \\ Submitted: \\ 03-08-2021 \\ Revised: \\ 29-08-2021 \\ Accepted:}

30-08-2021

DOI:

https://doi.org/10.53713/nhs.v1i2.45

\section{(c) (1) (2)}

This work is licensed

under CC BY-SA License.

\begin{abstract}
In the era of the COVID-19 pandemic, the use of personal protective equipment (PPE) is very important to reduce the risk of transmitting infectious diseases to medical personnel because it can prevent contact with pathogens. This shows that midwives as first-line managers of pregnancy, childbirth and postpartum cases must be vigilant by wearing complete Personal Protection Equipment (PPE) so that there is no transmission of the virus from the patient to the midwife. This study aimed to determine the analysis of midwives' practices in using PPE when assisting labor during the COVID-19 pandemic at the Banten Regional General Hospital 2020-2021. This is a quantitative analytic study using a cross sectional approach. The sample in this study was 102 respondents with purposive sampling technique. Data were analyzed using SPSS with Chi Square, which previously tested the validity and reliability. The results showed that the use of PPE in midwives in Banten Hospital obtained an average value of 84.3. Based on age, the average value was 53.9. Based on the length of service, the average score was 96.1. Based on education, the average score is 55.9. The results of the chi-square test showed that all independent variables had no relationship with the use of PPE including knowledge $(p=0.323)$, attitude $(p=0.665)$, availability of PPE ( $p$ $=0.740)$, and supervision $(p=0.603)$. It can be concluded that the use of PPE in midwives has no relationship with knowledge, attitudes, availability of PPE and supervision. There is a need for socialization about the importance of using PPE to midwives in order to maintain the quality of expected care services. There is a need for an $\mathrm{K} 3$ unit in Banten Hospital which is one of the authorities. There needs to be special attention from the Hospital Management regarding the supervision of the use of PPE in midwives.
\end{abstract}

Keywords: personal protective equipment, knowledge, attitude, supervision

\section{INTRODUCTION}

According to the World Health Organization (WHO), the incidence of cancer from 2008 to 2012 has Corona virus disease 2019 (COVID-19) is a disease that is endemic in almost all of the world at this time so that it has been declared a pandemic, with the name of the Severe Acute Respiratory Syndrome Coronavirus-2 (SARSCOV2) virus. It was starting from the Wuhan area, Hubei province, China which reported the first case of pneumonia of unknown cause.

The main clinical symptoms that appear in Covid-19 patients are fever (temperature $>38^{\circ} \mathrm{C}$ ), cough and difficulty breathing. In addition, it can be accompanied by severe shortness of breath, fatigue, myalgia, gastrointestinal symptoms such as diarrhea and other respiratory symptoms. Half of patients develop shortness of breath within one week. In severe cases rapidly and progressively worsens, such as ARDS, septic shock, uncorrected metabolic acidosis and bleeding or coagulation system dysfunction within a few days. In some patients, symptoms appear mild, not even accompanied by fever. Most patients have a good prognosis, with a small proportion in critical condition or even death.

Initially, this Corona virus mostly attacked the elderly group, but recently it has infected all age groups, ranging from productive ages, teenagers, toddlers, infants, including the group of pregnant women. Data obtained from the Health Office of Banten Province, Tangerang Regency area at most with 30,047 pregnancies. Then, Tangerang City 12,335, Serang Regency 10,163, Lebak 8,843 followed by South Tangerang City 8,411. Furthermore, Pandeglang Regency 8,239, Serang City 4,212, and Cilegon City 2,614 pregnant women during the period January to April 2020. This shows that midwives as first-line managers of pregnancy, childbirth and postpartum cases must be vigilant by wearing complete Personal Protective Equipment (PPE) so that there is no transmission of the virus from the patient to the midwife (Husein, 2020). 
The Indonesian Obstetrics and Gynecology Association (POGI) issued a number of recommendations in handling pregnant women and mothers giving birth to prevent the transmission of Covid-19 to mothers, babies and health workers. POGI asks that all deliveries must be carried out in health facilities such as health centre, midwives, and hospitals, during the Covid-19 outbreak. The main purpose of delivery at health facilities is to reduce the risk of transmission to health workers and prevent maternal morbidity and mortality. Moreover, $13.7 \%$ of pregnant women without symptoms can show positive results for Covid-19 by means of a polymerase chain reaction (PCR) examination. Therefore, birth attendants must use personal protective equipment (PPE) at least according to level 2. This level 2 (two) PPE is used by doctors, nurses, laboratory workers, radiographers, pharmacists, and cleaning staff for COVID-9 patient rooms. This level is used when medical personnel, doctors and nurses, in the polyclinic room when examining patients with symptoms of respiratory infections. The PPE consists of a 3-ply surgical mask, hazmat, disposable rubber gloves, and eye protection. This standard can only be guaranteed if the delivery is carried out in a health facility. PPE level 1 consists of headgear, surgical mask, gloves, work clothes and footwear. PPE level 2 consists of headgear, goggles, N95 mask, gloves, apron/gown and footwear. PPE level 3 consists of goggles, N95 masks, gloves, Cover All Jumpsuits and boots.

Delivery assistance for patients under supervision (PDP) or patients with confirmed Covid-19, the process must be carried out by cesarean section with various conditions. The first requirement, carried out in the operating room that has a negative pressure. Second, the operating team uses PPE according to level 3 . If there are no operating room facilities that meet the requirements, the delivery process for PDP or confirmed Covid-19 patients can be done with alternatives. One of them is by using a modified cesarean section in the operating room, such as turning off the air conditioner or other possible modifications.

Normal delivery can be carried out with special conditions, namely using a delivery chamber and a team of health workers must use PPE according to level 3. Starting in May, several health facilities in the Banten district have used delivery chambers to prevent transmission to mothers, babies, and health workers. This third level of PPE is intended for procedure rooms and operations for patients with suspected or confirmed COVID-19. For doctors, nurses and midwives, they are required to use N95 masks or its equivalent, special hazmat, boots, eye protection or face shields, disposable sterile rubber surgical gloves, head coverings, and aprons. In addition to doctors and medical personnel at the hospital, other officers who are required to wear PPE are ambulance drivers. They are required to use 3-ply surgical masks, disposable rubber gloves and a hazmat when raising and lowering patients suspected of COVID-19 (Widnyana \& Widyawati, 2020).

In this era of the COVID-19 pandemic, the use of personal protective equipment (PPE) is very important to reduce the risk of transmitting infectious diseases to medical personnel because it can avoid contact with pathogens. Things that medical personnel need to know regarding PPE are the types, how to remove them, and how to improve the compliance of medical personnel in using PPE.

Personal protective equipment (PPE) is a set of safety equipment used by workers to protect all or part of their bodies from the possibility of exposure to potential hazards of the work environment to accidents and occupational diseases (Alfanti \& Sawitri, 2017). Midwives are required to use Personal Protective Equipment to avoid occupational safety and health risks in hospitals in providing midwifery care. There are several factors related to the compliance of midwives to use PPE.

Health workers, midwives who work in this section, are very at risk of contracting infections because they are caused by pathogens such as HIV, hepatitis $C$ virus and hepatitis $B$ virus. AIDS because when they perform medical procedures, what happens is that midwives will often make contact with the patient's blood and body fluids through splashes on the mucosa of the eyes, mouth, and nose.

Factors that influence the practice of using PPE, predisposing factors include knowledge, attitudes and actions, enabling factors (enabling) include health facilities and infrastructure, the availability of personal protective equipment and reinforcing factors (reinforcing factors) including regulations or policies that apply in hospitals related to the use of personal protective equipment by Banten Regional Hospital officers. Because it is undeniable that using personal protective equipment for midwives can prevent accidents and occupational diseases as well as avoid infections in the Banten Regional General Hospital. The researcher is interested in conducting research on "The practice of midwives in the use of personal protective equipment during delivery assistance during the COVID-19 pandemic at the Banten Regional General Hospital in 2020-2021". 


\section{METHOD}

The research used is a quantitative analytic research using a cross sectional approach, where the researcher measures the independent variables and the dependent variable whose data collection is carried out in a certain period and observations are only made once during the study (Notoatmodjo, 2005). The case in this study was a midwife at RSUD Banten. The population in this study was all midwives in the Maternal Emergency Room, Maternity Room, Inpatient Room and Outpatient Room at Banten Hospital, totaling 102 people. The sample is the total population. The instrument used in this study was a questionnaire about knowledge, attitudes, and practices related to the use of personal protective equipment. The questionnaire was formulated by the researcher and has been tested for validity and reliability. This study has been approved the permission from Universitas Nasional and RSUD banten. There is no conflict of interest for conducting the study.

\section{RESULT}

Table 1. Demographic Characteristic of the Respondents

\begin{tabular}{|c|c|c|}
\hline Variables & $\mathrm{n}$ & $(\%)$ \\
\hline \multicolumn{3}{|l|}{ Age } \\
\hline $20-30$ & 55 & 53.9 \\
\hline $31-40$ & 42 & 41.2 \\
\hline $41-50$ & 4 & 3.9 \\
\hline $51-60$ & 1 & 1.0 \\
\hline \multicolumn{3}{|l|}{ Working experience } \\
\hline$\leq 5$ years & 4 & 3.9 \\
\hline$>5$ years & 98 & 96.1 \\
\hline \multicolumn{3}{|l|}{ Education } \\
\hline D III midwifery & 57 & 55.9 \\
\hline D IV midwifery & 42 & 41.2 \\
\hline Midwifery profession & 0 & 0 \\
\hline Master & 3 & 2.9 \\
\hline \multicolumn{3}{|l|}{ Knowledge } \\
\hline Good & 97 & 95.1 \\
\hline Less & 5 & 4.9 \\
\hline \multicolumn{3}{|l|}{ Attitude } \\
\hline Good & 101 & 99.0 \\
\hline Less & 1 & 1.0 \\
\hline \multicolumn{3}{|l|}{ Availability of PPE } \\
\hline Complete & 73 & 71.6 \\
\hline Not complete & 29 & 28.4 \\
\hline \multicolumn{3}{|l|}{ Observation } \\
\hline Yes & 92 & 90.2 \\
\hline No & 10 & 9.8 \\
\hline \multicolumn{3}{|l|}{ The use of PPE } \\
\hline Appropriate & 86 & 84.3 \\
\hline Not appropriate & 16 & 15.7 \\
\hline
\end{tabular}

Table 1 shows that out of the 102 respondents, 55 midwives (53.9) aged 20-30 years, 98 midwives (96.1\%) who worked more than 5 years, 57 midwives (55.9\%) have D III of midwifery education, 97 midwives (95.1\%) had good knowledge in the use of PPE, 101 midwives (99.0\%) had a good attitude in using PPE, 73 midwives $(71.6 \%)$ said the availability of PPE was complete, 92 midwives $(90,2 \%)$ said there was supervision in the use of PPE, 86 midwives (84.3) said it was appropriate to use PPE. 
Table 2. Analysis related to the practice of midwives in the use of PPE

\begin{tabular}{|c|c|c|c|c|c|c|c|c|}
\hline \multirow{3}{*}{ Variable } & \multicolumn{4}{|c|}{ The use of PPE } & \multirow{2}{*}{\multicolumn{2}{|c|}{ Total }} & \multirow{3}{*}{$p$-value } & \multirow{3}{*}{ OR } \\
\hline & \multicolumn{2}{|c|}{ Approriate } & \multicolumn{2}{|c|}{ Not appropriate } & & & & \\
\hline & $n$ & $\%$ & $\mathrm{n}$ & $\%$ & $n$ & $\%$ & & \\
\hline Good knowledge & 81 & 83.5 & 16 & 16.5 & 97 & 100 & 0.323 & 1.754 \\
\hline Less knowledge & 5 & 100 & 0 & 0 & 5 & 100 & & \\
\hline Good attitude & 85 & 84.1 & 16 & 15.9 & 101 & 100 & 0.665 & 0.343 \\
\hline Less attitude & 1 & 100 & 0 & 0 & 1 & 100 & & \\
\hline Complete PPE & 61 & 83.6 & 12 & 16.4 & 73 & 100 & 0.740 & 0.112 \\
\hline Not complete PPE & 25 & 86.2 & 4 & 13.8 & 29 & 100 & & \\
\hline Observation & 77 & 83.7 & 15 & 16.3 & 92 & 100 & 0.603 & 0.301 \\
\hline No observation & 9 & 90 & 1 & 10 & 10 & 100 & & \\
\hline Total & & & & & 102 & 100 & & \\
\hline
\end{tabular}

From table 2 it is found that the results of the study indicate that respondents who have good knowledge were 97 respondents (95.1\%), compared to those who have less knowledge were 5 respondents $(4.9 \%)$. Respondents with the right use of PPE have more good knowledge (83.5\%) compared to those with less knowledge, (5\%). Respondents with inappropriate use of PPE have less knowledge $(0 \%)$, compared to those who have good knowledge $(100 \%)$. Based on the results of statistical tests, using the Chi Square $\left(\mathrm{X}^{2}\right)$ test on the knowledge variable, it was found that the P-value was (0.323), which means the P-value> 0.05 . So in this study, it can be concluded that there was no relationship between knowledge and the use of PPE in midwives at Banten Hospital in 2020-2021.

The results showed that the respondents who had a good attitude were 101 respondents (99.0\%), while the respondents who had less attitudes towards the use of PPE were 1 respondent $(1.0 \%)$. Respondents in using the right PPE have a good attitude (84.1\%) compared to the attitude of respondents who lack (100\%). Respondents in using inappropriate PPE showed a lack of attitude $(0 \%)$, compared to those who had a good attitude $(15.9 \%)$. The results of data analysis using the chi-square test obtained $p$ value $=0.665$ because the $p$ value $>0.05$. This shows that there was no relationship between attitudes and the practice of using Personal Protective Equipment in midwives at Banten Regional Hospital in 2020-2021.

The results showed that the number of complete PPE was $73(71.6 \%)$, while the incomplete were $29(28.4 \%)$. The results of data analysis using the Chi-Square test showed that the value ( $p$ value $=0.740$ ), because $p>0.05$. The interpretation is that there was no relationship between the availability of PPE and the use of PPE in midwives at the Banten Regional General Hospital in 2020-2021.

. The results showed that from the number of people who had supervision $(90.2 \%)$, while those who did not have supervision were $(9.8 \%)$. Respondents with the proper use of PPE were 77 respondents (83.7\%). Compared to the statement of respondents who said that there was no supervision were $9(90 \%)$. Respondents with inappropriate use of PPE stated that there were 15 respondents (16.3\%) supervision, compared to 1 respondent (10\%). There was no significant relationship between supervision and the practice of using PPE, where the statistical test results obtained that the value ( $p$ value $=0.603$ ), because $p>0.05$. This means that there was supervision or no supervision does not affect the practice of using PPE. There is self-awareness in respondents to always use PPE at work.

\section{DISCUSSION}

Knowledge is one of the factors that shape or influence a person's behavior Ryu, S., Ho, S. H., \& Han, I. (2003). Good knowledge or lack of knowledge does not always lead to the discipline to obey using PPE when working. This is because knowledge is only limited to or the first level of knowledge, which is knowing. Knowledge is the result of knowing, and occurs after people sense a certain object. Knowledge or cognitive is a very important domain in shaping one's actions (overt behavior). Knowledge is the result of individual observation and experience of a new thing that can be useful for the individual. This is in line with the research of Arifi \& Susanto, 2014) which found there was no relationship between worker knowledge and operator worker compliance in the use of PPE. The researcher assumes that the number of respondents who are not right on duty are mostly midwives who work in the Inpatient Room and in the Outpatient Room at RSUD Banten.

Although through the questionnaire, it was found that the midwife's knowledge of PPE was good, such as knowing the meaning of PPE, the benefits of PPE when working, and midwives also already knowing what standard PPE must be used in the Maternal Emergency Room, Maternity Room, Inpatient Room, Outpatient Room and this set of personal protective equipment is evidenced by the results of the answers to several questions regarding PPE. However, 
the reality in the field is that there are still midwives who do not use standard PPE when performing actions on patients such as masks, gloves, protective gowns (aprons), head coverings and closed shoes.

This research showed that there was no relationship between attitudes and the practice of using Personal Protective Equipment in midwives at the Banten Hospital in 2020-2021. Attitude is a reaction or response that is still closed from a person to a stimulus or object. Mental states and readiness that are regulated through experience, exert a dynamic or directed influence on the individual's response to all objects and situations related to them. Attitudes clearly show the connotation of a suitability of reactions to certain stimuli (Vandermeeren, 2008). This is in line with research conducted by Moore et al., (2005) which states that there was no relationship between attitudes and compliance with the use of PPE in herbal medicine production workers with the chi-square test, a p value of 0.050 is obtained.

Researchers assumed that the factors that influence the absence of a relationship between attitudes and compliance with the use of PPE are personal experience factors and emotional factors. To be able to form the basis of attitude formation, personal experience must leave a strong impression, therefore attitudes will be more easily formed if the personal experience occurs in situations involving emotional factors. Sometimes attitudes are statements based on emotions (Matta et al., 2006). Someone who has a bad attitude has a tendency to stay away from, avoid, hate or dislike certain objects, the respondent's negative attitude towards personal protective equipment can be caused by a bad experience with the use of personal protective equipment or policies that do not support the use of personal protective equipment.

The results showed that there was no relationship between the availability of PPE and the use of PPE in midwives at the Banten Regional General Hospital in 2020-2021. The availability of PPE is a supporting factor in compliance with using PPE to prevent accidents and work risks that occur in the company, if the company does not provide PPE, it means the company has endangered its workers from the risk of accidents and diseases that will arise in the work environment. Therefore, the company applies rules to provide personal protective equipment in accordance with their respective jobs (Prasetyo, Musyarofah, Muliawati \& Widjasena 2020). This is in line with the research conducted by Saputri \& Paskarini (2014) which stated that the fisher exact results showed that there was no relationship between the availability of PPE and compliance with the use of PPE for building frame workers. This is because the PPE provided by the company is not adequate available. Another assumption that the availability of PPE is due to a lack of worker motivation.

Motivation will give rise to an urge to do something both from within and from outside the respondent. So if the respondent's motivation is high to do a job, for example in using personal protective equipment, even though there are obstacles to doing so, but because of this motivation, the respondent will try to maintain his health or prevent the risk of work accidents. What is expected will be lacking especially when there are obstacles and obstacles. In addition, motivation can be defined as goal-oriented behavior. Other reasons for not using PPE are busy, unfamiliar, forgetful, and lazy (Hayulita \& Frenky, 2014).

The researcher assumes that in this study, midwives who work in the Maternal Emergency Room, Maternity Room, Inpatient Room, Outpatient Room at RSUD Banten assess that the availability of PPE in RSUD Banten is still incomplete, this is evidenced by the answers from the midwives through questionnaires, that although it has been socialized about PPE, some PPE is indeed not available and not enough in hospitals such as gloves, closed shoes, protective gowns/aprons and masks. The availability of PPE that is not in accordance with standard procedures causes the behavior of midwives who do not use PPE when carrying out medical procedures. Another thing that causes the availability of PPE is not enough because one of them, RSUD Banten is still a type $C$ hospital where all the facilities and infrastructure are still limited, and is currently in the process of gradually completing the hospital accreditation process. In addition, the availability of facilities and infrastructure, including PPE, is highly dependent on the capacity of the Banten Province's regional budget. From the results of the research, the problems that occurred were as stated by several midwives at the Banten Regional Hospital that the use of PPE was adjusted to the patients treated by each midwife, for example, the PPE used by midwives who worked in the treatment room for patients suffering from pulmonary TB and COVID-19. The PPE used will be different from the PPE used by midwives who work in inpatient rooms who only treat patients suffering from diseases, for example hypertension. So that the availability of PPE that must be used at work must be in accordance with the needs of every medical procedure performed by the midwife, with the aim of protecting herself and the people around her so as not to risk or endanger health.

Based on research conducted on midwives at Banten Regional Hospital, the results showed that there was no significant relationship between supervision and the practice of using PPE. This means whether by supervision or without supervision will not affect the practice of using PPE. There is self-awareness in respondents to always use PPE at work. Supervision is a motivating or reinforcing factor for the occurrence of a behavior. The existence of a policy can be a factor for someone to comply with the use of PPE in carrying out their treatment. Every violation committed against the established policy will be subject to sanctions (Harisudin \& Choriri, 2021). 
According to Azwar (1998) in Hendrabuwana (2007) that the existence of supervision and the regulations that follow it is one of the thick factors that will affect a person's behavior. Furthermore, supervision is one of the environmental factors in the workplace, precisely as an organizational variable that can influence the emergence of unsafe behavior when supervision from supervisors is low (Novelia, Sia \& Songwathana, 2017; Novelia, Usman, \& Pamungkas, 2021). Supervision of the use of PPE in hospitals is very important, because with this supervision, midwives will be able to know more about the importance of using PPE, so as to prevent work accidents when carrying out medical procedures on patients. This is in line with research conducted by Dachi (2019) that the supervision variable with a significant value of $0.107>0.05$, it can be concluded that partial supervision has no significant effect on the use of PPE. Oversight of Occupational Safety and Health (K3) to ensure compliance with OHS provisions, so that unsafe and unhealthy conditions and behavior can be detected early on. Researchers assume that supervision related to the procedure for using PPE for its use when carrying out medical procedures on patients at RSUD Banten is still lacking. This is because the OSH policy implemented in hospitals has not been implemented properly.

RSUD Banten, which is one of the missions to improve the facilities and infrastructure of this health service, some of its midwives have not complied with the policies related to the applicable procedures for using PPE. The noncompliance of midwives in using PPE when performing medical procedures on patients was because the midwife felt uncomfortable and did not meet the PPE requirements that should be in the Banten Hospital. In addition, the lack of supervision and socialization is the reason for their non-compliance.

Regulations are often ignored, this is due to a lack of supervision and socialization. Therefore, the regulations must be firm and have consequences if they are violated. The policy regarding the use of PPE itself is regulated in Law Number 23 of 1992 concerning Health, Article 23 that Occupational Health and Safety (K3) efforts must be carried out in all workplaces, especially workplaces that have health risks, are susceptible to disease. Therefore, the hospital management should implement $\mathrm{K} 3$ efforts in hospitals.

\section{CONCLUSION}

It can be concluded that there is no relationship between knowledge, attitude, availability of PPE, and Supervision with the use of PPE. It is hoped that the Banten Hospital needs socialization about the importance of using PPE in midwives in order to maintain the expected quality of care services. There is a need for an K3 unit at the Banten Regional Hospital, one of whose authorities is to regulate all PPE supplies in hospitals, both in the Maternal Emergency Room, Maternity Room, Inpatient Room, Inpatient Outpatient Room and other units in Banten Hospital, so that all needs related to PPE in hospitals can be quickly followed up. There needs to be special attention from the Hospital Management regarding the supervision of the use of PPE in midwives as stated in Law Number 23 of 1992 concerning Health, Article 23 that Occupational Health and Safety (K3) efforts must be carried out in all workplaces, especially workplaces which have a risk of health hazards, and are susceptible to disease.

\section{REFERENCES}

Alfanti, G., \& Sawitri, D. R. (2017). Safety Climate and Construction Workers' Compliance on the Use of Personal Protective Equipment in Construction Project Jakarta. Advanced Science Letters, 23(4), 3399-3401.

Arifi, A.B., dan Susanto, A. (2014). Faktor-faktor Yang Berhubungan Dengan Kepatuhan Pekerja Dalam Pemakaian Alat Pelindung Diri (APD) Di Bagian Coal PT X Unit 3 dan 4 Kabupaten Jepara Tahun 2012. Fakultas IImu Kesehatan UNDIP. Jurnal Kesehatan Masyarakat, 1(1), 2014.

Dachi, R. A., Awwalu, S., Waziri, A. D., Hassan, A., Okpe, I. O., \& Suleiman, A. M. (2019). Burden and Correlates of Anaemia Among Patients With Diabetes Mellitus in a Tertiary Health Facility in Northwestern Nigeria. West African journal of medicine, 36(2), 133-137.

Hayulita, S., \& Frenky, P. (2014). Hubungan Motivasi dengan Penggunaan Alat Pelindung Diri oleh Perawat Pelaksana di Ruang Rawat Inap RSI Ibnu Sina Bukittinggi.

Hendrabuwana, L. O. (2007). Faktor-Faktor yang Berhubungan dengan Perilaku Bekerja Selamat Bagi Pekerja di Departemen Cor PT. Pindad Persero Bandung Tahun 2007. Skripsi. Depok: FKM UI.

Matta, S., Bhalla, S., Singh, D., Rasania, S. K., \& Singh, S. (2006). Knowledge, attitude and practice (KAP) on dengue fever: a hospital based study. Indian Journal of Community Medicine, 31(3), 185-186.

Novelia, S., Sia, W. S., \& Songwathana, P. (2017). Nurses' knowledge and practice regarding the prevention of cesarean section surgical site infection in Indonesia. GSTF Journal of Nursing and Health Care (JNHC), 4(2).

Novelia, S., Usman, A. M., \& Pamungkas, R. A. (2021). Perceived Stress among Health Care Workers of an Emerging Infectious Covid-19 Outbreak in Indonesia. Asian Community Health Nursing Research, 9-9. 
Prasetyo, A. D., Musyarofah, S., Muliawati, R., \& Widjasena, B. (2020). The Relationship of Personal Hygiene and the Use of Personal Protective Equipments with Dermatitical Complaints in Fisherman of Sugih Waras Village Pemalang District. In Proceedings of the International Conference on Nursing and Health Sciences, 1(1), 187-194.

Ryu, S., Ho, S. H., \& Han, I. (2003). Knowledge sharing behavior of physicians in hospitals. Expert Systems with applications, 25(1), 113-122.

Saputri, I. A. D., \& Paskarini, I. (2014). Faktor-faktor yang berhubungan dengan kepatuhan penggunaan APD pada pekerja kerangka bangunan. Universitas Airlangga, Surabaya.

Vandermeeren, S. (2008). Research on language attitudes. In Sociolinguistics (pp. 1318-1332). De Gruyter Mouton.

Widnyana, I. W., \& Widyawati, S. R. (2020). Supply of Consumer Goods, Per Capita Consumption due to Covid-19 Pandemic. Economics Development Analysis Journal, 9(4), 458-467. 